\title{
Ouderlinge met preekvergunning: 'n Herlewing van Dordtse Kerkorde artikel 8?
}

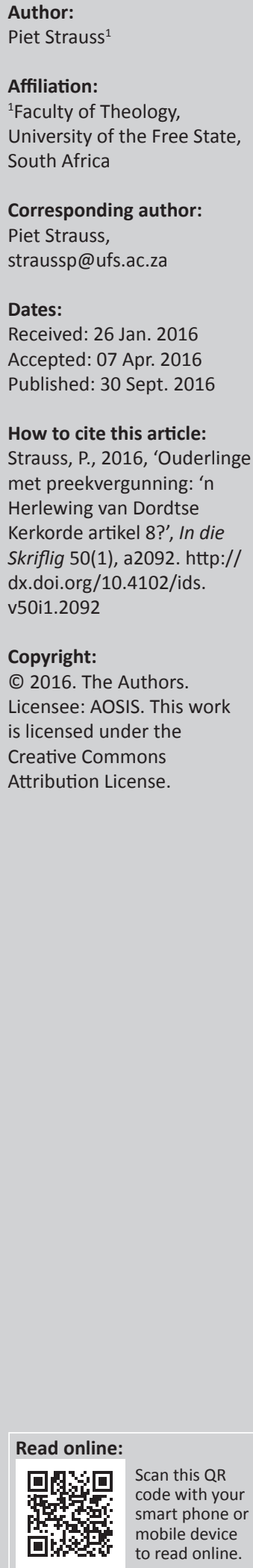

\begin{abstract}
Elders with consent to preach: A revival of Church order of Dordt (DCO) art 8? There seems to be a need for members other than trained ministers to preach in Reformed Churches. This need comes to the fore especially during periods in which traditional academically trained ministers are lacking. The well-known Synod of Dordt (1618-1619) made provision for members with extraordinary (singular) gifts to become ministers of the Word. In this it was continuing a practice in the Reformed Churches in the Netherlands of the 16th century. Other reformed churches followed. In the Dutch Reformed Church elders with the necessary abilities who are trained in short spells are nowadays also used to preach the Word. This article investigates the latter in the light of the former and the content of article 8 of the Church order of Dordt (DCO).
\end{abstract}

\section{Inleiding en probleemstelling}

Skynbaar skep die probleem van plattelandse gemeentes wat te klein is om 'n predikant te onderhou én beskikbaarheidsprobleme van ander predikante om die bediening van die Woord en die sakramente in hierdie gemeentes te behartig, ' $n$ behoefte aan (gewone) belydende lidmate met preekvergunning in die Nederduitse Gereformeerde Kerk (NGK). Reëlings om in hierdie behoefte te voorsien, word reeds vervat in die NGK-Kerkorde (NGKO vgl. NGKKO 2013:13) en, byvoorbeeld, die Kerkorde van die NGK in Oos-Kaapland (OKKO). Laasgenoemde het daarvoor bepalings by artikel 16 van die NGKO (OKKO 2014:I-16, I-17, I-18).

Die saak kom die eerste keer in die NGKO voor in 2011. Artikel 48.3.5 van NGKO-2011 bepaal dat 'n ouderling wat preekvergunning van die kerkraad en ring ontvang het, eredienste kan lei. Drie sleutelbegrippe kom in hierdie reëling voor: ouderling, preekvergunning en kerkraad/ring. Dit gaan dus om die volwaardige leiding van eredienste deur ' $n$ ouderling wat deur die kerkraad en die ring waarin die gemeente voorkom, daartoe gemagtig is; preekvergunning waarby die eie gemeente en die naaste vergadering van die kerkverband (ring) betrek is. Preekvergunning en nie die tradisionele lees van preke van erkende predikante nie, wat as 'n vergunning uit die plaaslike omgewing geïnisieer word. ' $n$ Saak wat anders hanteer word as die betrokkenheid van die sinode en algemene sinode - die breë kerkverband - by die legitimering van opgeleide predikante (NGKO 2011:2-3).

Die onmiddellike probleem omtrent ouderlinge met preekvergunning is tweërlei. Eerstens is dit 'n vraag watter prosedure by hierdie vergunning gevolg word én, tweedens, watter kwaliteite by die betrokke lidmaat tot hierdie vergunning kan lei?

Teen die agtergrond van die geskiedenis van gereformeerde kerke in die Nederlandse tradisie skep hierdie saak nog ' $n$ vraag: kom ouderlinge met preekvergunning of lidmate wat as ouderlinge met preekvergunning verkies word, reeds in die geskiedenis van hierdie kerke voor? Hoe vergelyk die kwessie van ouderlinge met preekvergunning met die Dordtse Kerkorde (DKO) van 1619 (Pont 1981:171), artikel 8? Daardie bekende artikel oor 'niet-gestudeerde' predikante met 'singuliere' gawes (vgl Bouwman 1985:434-439; Bos 1950:40; Jansen 1952:40-45; Kruger et al. 1966:78; Spoelstra 1989:72-77; Visser 1999:45-46). Is ouderlinge met preekvergunning 'n nuwe verskynsel in die gereformeerde tradisie of is daar reeds voorbeelde hiervan? Hoe vergelyk die hantering van die saak van 'niet-gestudeerde' predikante in die 21ste eeu met die hantering daarvan in die 17de eeubyna 400 jaar gelede? Anders gestel: hoe vergelyk die huidige hantering van die saak met die hantering daarvan in die steeds rigtinggewende - in talle gereformeerde kerke - DKO van 1619 (vgl Nauta 1971: 20-35; Strauss 2010:7-13; Visser 1999:44)? 1.By die betrokke kerkorde wat hierdie skrywers hanteer, naamlik respektiewelik van die Gereformeerde Kerke in Nederland (GKN), die
Gereformeerde Kerke in Suid-Afrika (GKSA) en die NG Kerk (NGK), gaan dit - tot mindere of meerdere mate - oor die DKO aangepas by die eise van die dag (Strauss 2010:7-8). 
'Singuliere' gawes dui op buitengewone gawes. Gawes wat by uitsondering voorkom. So oordeel die kerkhistorikus JC Rullman dat hy dit oor ' $\mathrm{n}$ man met buitengewone gawes het as hy 'n biografie lewer oor ds W.H. Gispen: Een man van singuliere gaven (Rullman 1933).

Die relevansie van so 'n vergelykende studie word onderstreep deur die waarneming dat baie van die bepalende konstantes agter die artikels van die DKO vandag nog in gereformeerde kerke aanvaar word. Konstantes wat die prinsipiële kant vorm van 'n gereformeerde aanpak van ondermeer die ampte en kerkregering (Strauss 2010:7-13). In sy studie oor die kerklike bediening en ampte praat Du Toit van konstantes of 'blywendgeldige' norme vir hierdie bediening (Du Toit 1998:217). In hierdie artikel word die konstantes wat die DKO en sommige van sy kerklike nakomelinge gebruik, ook met mekaar vergelyk.

Een van die konstantes is dat die hele kerklike lewe onder die regering van die Woord en Gees van God staan. Dit beteken dat die omgang tussen God en sy gemeente draai om die verkondiging van die Woord - op verskeie maniere waaronder die bediening van die sakramente - en die 'belijdend antwoord daarop' van die gemeente. Volgens Koffeman bepaal hierdie Woord-antwoordkarakter van die omgang die struktuur en inhoud van die kerk fundamenteel (Koffeman 2009:137).

Kort saamgevat beteken hierdie benadering dat die kerklike ampte of dienste spruit uit die regering van en daarmee die diens van die hoof van die kerk, Jesus Christus, aan sy kerk. Woordgetroue ampsdiens is Christus-gehoorsame ampsdiens. Woordgetroue ampsdiens gaan uit van Christus wat mense daarvoor roep, toerus en begelei (Kleynhans 1984:8-9). Dit doen Hy deur sy Woord en Gees én deur die bevestiging en implimetering daarvan deur die kerk as 'n herskape werklikheid. Spoelstra oordeel dat die kerklike examinatio (ondersoek, toelating) volg op die Goddellike vocatio [roeping]. Hierdie examinatio moet die vocatio bevestig (Spoelstra 1989:73). ${ }^{2}$

Die implikasie hiervan is dat die toerusting van Christus ' $n$ geskenk of genadegawe (charisma) is en dat die vermoë om die amp te vervul - die amp self - ook 'n genadegawe is (Smit 1984:29, 32, 124-125). Christus werk op twee maniere in sy kerk: direk deur sy Woord en Gees en indirek of deur middel van die ampte. In die reformatories-erkende bedienaar van die Woord, ouderling en diaken moet Christus as ons hoogste profeet, enigste hoëpriester en ewige koning woordgetrou (NG Kerk-Uitgewers 2004:47) bedien word. Woordbepaalde roeping, toerusting, toelating tot, bevestiging en diens in die amp van die bedienaar van die Woord, is in hulle kern blywendgeldig (Kleynhans 1984:29-44).

Hierdie konstantes moet dus sigbaar word by kerklikerkende en opgeleide predikante, DKO artikel 8-predikante

2.Trimp 1988:240 praat van aanwysing, mandatering, installering en bekwaammaking vir die ampsdiens. ' $n$ Proses waarin God die gemeente gebruik en waarin die wil van God ook korporatief beluister en verstaan moet word. met hulle singuliere gawes én ouderlinge aan wie die kerk die vergunning verleen om die Woord amptelik te bedien. In aldrie gevalle gaan dit oor roeping, toerusting, toelating, bevestiging en diens waarin Christus én sy kerk hulle rolle speel.

Hierdie artikel konsentreer dus op die kerklike prosedure om aan ouderlinge preekvergunning te gee en die vraag hoe dit vergelyk met die van DKO-1619 artikel 8. Om sake sinvol met artikel 8 te vergelyk, kom die inhoud hiervan eerste aan die bod. Daarna word die NGK se huidige hantering van die saak belig. In die proses word daar ook gekyk na laasgenoemde se hantering van 'n soortgelyke saak in die twintigste eeu: 'oefenaars' met beperkte predikantsopleiding, maar preekvergunning.

In die evaluering van hierdie prosedure kry bepalende konstantes soos ' $n$ Goddellike roeping en toerusting en die kerklike komplementering en bevestiging daarvan, ook aandag. In alle gevalle staan die gesagvolle (suiwere), amptelike verkondiging van die Woord as die konstante lewensaar van die kerk, voorop.

\section{DKO 1619 artikel 8: Besondere gawes}

Die DKO van 1619 hanteer die tema 'Niet gestudeerde predikanten' in artikel 8 (Pont 1981:177).

Hierin word bepaal dat 'schoolmeesters, handwerkslieden, of anderen die niet gestudeerd hebben' nie tot die predikantsamp toegelaat sal word nie tensy hulle die kerk oortuig van hulle 'singuliere gaven'. Onder hierdie gawes plaas hy 'godzaligheid, ootmoedigheid, zedigheid, goed verstand ... discretie ... en welsprekendheid'. Dit gaan op die oog af dus om gawes wat pas by die predikantsamp. Persone wat hulle in hierdie kategorie aanbied, doen dit by die (partikuliere of provinsiale) sinode wat hulle na goedkeuring aan die betrokke klassis (waaruit hulle kom) vir eksaminering oorhandig. Slaag hulle hierdie eksaminering, moet hulle 'n tydlank 'privé proponeeren' of onder toesig van 'n begeleier(s) preek (Pont 1981:177). Die Konvent van Wezel in 1568 en die Sinode van Emden in 1571 beoog 'private proposities' of praktiese oefenskole in die groter of meer 'aanzienlijke' gemeentes. Hierin sou kandidate vir singuliere gawes onder leiding van een van die predikante kon preek (Jansen 1952:41). Kruger et al. praat van 'private preekproewe lewer (Kruger et al. 1966:80). Hierna - volgens DKO artikel 8 - kan die klassis hulle 'stichtelijk' hanteer. Hierdie stigtelik beteken moontlik kerklik-broederlik en daarom kerkordelik (Pont 1981:177).

Die eerste vraag wat hierdie artikel skep, is die vraag wat as 'singuliere' gawes beskou word. Jansen wys daarop dat ' $\mathrm{n}$ komma na die Nederlandse '... singuliere gaven, ...' in artikel 8 die indruk mag skep dat 'singuliere' gawes naas gawes soos godsaligheid as aspekte van dieselfde lysie beskou word. Hy vra vir 'n dubbelpunt: '... singuliere gawes: godzaligheid ...' (Jansen 1952:42). Dit beteken '... singuliere gawes zo als godzaligheid ...' 
Die implikasie hiervan is dat artikel 8 op buitengewone gawes gerig bly. Hierdie vertolking word deur kerkregtelikes met sekere terme gehandhaaf.

Kruger et al. praat van die uitsondering op die geldende reël. Vir hulle gaan dit oor buitengewone maatreëls wat die kerke in buitengewone tye tref. Sulke tye was die Reformasie van die16de eeu, die afskeiding van dieChristelike Gereformeerde Kerk in Nederland in 1834 en die 'Dopperse' afskeiding in Suid-Afrika van 1859. In hierdie tye moet die kerk volgens hulle oor die vermoë beskik om 'sy bekwaamste manne' tot die diens van die Woord toe te laat al ontbreek daar by dié manne 'n relevante, deeglike, sistematiese akademiese opleiding. Immers, so lui die argument, '... in sy vrymag skenk God aan sommige buitengewone gawes en bekwaamhede'. Hulle weg tot die diens van die Woord word in DKO artikel 8 aangedui (Kruger et al. 1966:78).

Bos bou sy argument op die besluite van gereformeerde sinodes in die Nederlandse kerkgeskiedenis na Dordt 1619. Hy wys op beskrywings soos buitengewone of 'singuliere kwaliteiten en gaven', die aanwesigheid hiervan by 'n kandidaat 'boven alle billijke twijfel verheven' en gawes wat die persoon 'in bizondere mate bezitten moet'. Dit gaan oor 'n kandidaat wat bo alle redelike twyfel ' $n$ diepe insig in die Woord van God het. 'n Waarneming wat ook uit die kring waaruit die persoon kom, sy eie kerkraad en klassis, bevestig moet word (Bos 1950:42-43). Daarop kom ek terug.

Vir De Gier kom persone met singuliere gawes 'ver boven de middelmaat' uit in hulle geskikheid vir die amp. Vir hom gaan dit oor mense wat besondere gawes van die Here ontvang het. Gawes wat ander mense deur studie en harde werk verwerf. Hy wys daarop dat die Reformasie die nodigheid ingesien het van opgeleide predikante. Hervormers soos Luther, Calvyn en Zwingli het 'n studie van die Bybel, Godgeleerdheid en klassieke en Bybelse tale as noodsaaklike voorbereiding vir predikante beskou.

Van der aanvang der reformatie af kwam het echter in de praktijk van het kerkelijk leven voor dat mannen met singuliere gaven zonder enige wetenschaplijke opleiding tot de dienst des Woords en der sacramenten werden toegelaten. (De Gier 1989:58)

'n Uitleg van hierdie singuliere gawes bevestig hulle buitengewone, maar ook normaal Bybelse aard: hulle word deur die Here aan mense gegee vir die verkondiging van Sy Woord. Jansen (1952:43) gee van die gawes 'n uitleg wat deur ander nagevolg word (De Gier 1989:59-60; Kruger et al. 1966:78-79).

\section{Singuliere gawes}

Godsaligheid verwoord die Latynse pietas of vroomheid. Dit gaan oor iemand wat vol of vervul is met die Heilige Gees, vervul met geloof in en eerbied vir God-Drieënig. Vervulling met die Heilige Gees dui op talle plekke in die Skrif op

3.Pres Paul Kruger van die ou Zuid-Afrikaansche Republiek het in die 19de eeu ' $n$ DKO artikel 8 vergunning as ' $n$ prediker in die Gereformeerde Kerk in Suid-Afrika gehad. In die 20ste eeu het dieselfde voorreg proff F Postma en J.C. van Rooy te beurt geval (Kruger et al. 1966:82). toerusting - van gees en gawes - om die wil van God te verkondig en uit te voer (Strauss 1995:18-22). Godsaligheid beteken dus om met jou volle menswees aan God te behoort. Hierdie gawe is gewoon Bybels, maar in hierdie ondermaanse, sondige lewe juis daarom ook buitengewoon.

Ootmoedigheid verwoord die Latynse humilitas of nederigheid. Godsaligheid moet juis tot ootmoed in die uitlewing van buitengewone gawes lei. Ootmoed verskerp die besef dat jy uit die genade van God lewe. Ootmoed voorkom hoogmoed en selfverheffing en verskerp die besef van God se genade in die bedienaar van die Woord.

Ingetoënheid verwoord die Latynse modestia of beskeidenheid en selfbeheersing. Dit beperk valse of sleg gemotiveerde trots en 'n selfgesentreerdheid. 'n Goeie verstand is die wysheid van Spreuke naamlik om die Bybel in sy diepte te verstaan en uit te lê. Dit gaan oor die Latynse excellens ingenium of 'n skerpe begripsvermoë en insig met Skrifverklaring.

Diskresie of die Latynse prudentia om waar en vals of dwaas en wys in die verhoudinge tussen mense te onderskei en toe te pas is die volgende buitengewone gawe. Dit gaan om die balans tussen Skrifgehoorsaamheid en taktvolheid. Om die Woord op die gees van mense te kan toepas, en om mense te boei met jou praktiese Skrifwysheid. Ook hierdie gawe is buitengewoon in 'n sondige wêreld.

Die laaste singuliere gawe waarna DKO artikel 8 verwys, is welsprekendheid. In Latyn word gepraat van eloquentia. Die bedoeling is nie dat ' $n$ artikel 8-predikant net vlot moet kan praat nie. Selfs akademies opgeleide dominees kan dit nie almal doen nie. Dit gaan daarom dat so ' $\mathrm{n}$ persoon sy gedagtes ordelik, logies, helder en juis moet kan uitdruk tot die aandag en stigting van sy hoorders. Duidelikheid, eenvoud en ordelikheid is vereistes vir Skrifprediking. En getroue Skrifprediking is na sy aard in hierdie gebroke wêreld buitengewoon!

In die lig van ons probleemstelling maak De Gier 'n interessante opmerking. Volgens hom was mense met singuliere gawes nie 'oefenaars' nie. Hulle was nie gemeentelede wat net 'n stigtelike woord spreek nie, maar volwaardige predikante. Hulle was op 'n gelyke voet met opgeleide dominees. Die gewone weg tot die amp was: eers studie en dan eksamen. Die weg van DKO artikel 8 tot die amp was: geen opleiding voor die eksamen, maar opleiding en oefening na die eksamen (De Gier 1989: 60). In beide gevalle was die amp afhanklik van of doodgewoon 'n charisma.

Iemand wat oor hierdie singuliere gawes beskik, is ' $n$ goeie prediker. Selfs al het hy of sy nie akademiese opleiding nie. Bos haal die Sinode van Rotterdam van 1887 aan as hy aanvoer dat DKO artikel 8 nie 'n nooduitgang is om in 'n tydelike tekort aan predikante te voorsien nie. Hierdie artikel spruit uit eerbied vir God se vrymagtige genade om persone met ' $n$ besondere kennis van die Woord, van geestelike nood, van die toepassing van die Woord en van welsprekendheid aan die kerk tot sy 'profijt' te gee (Bos 1950:41). 
De Gier wys op enkele faktore wat predikers met singuliere gawes in die Nederland van die sewentiende eeu genoodsaak het. In Nederland was daar nog nie universiteite waaraan hulle opgelei kon word nie. Die nood van die tyd het ' $n$ kortpad na die amp vereis en daar was persone met besondere of singuliere gawes wat as predikers in gemeentes kòn dien. Die gereformeerde kerke het dankbaar van hierdie gawe van die Here gebruik gemaak. Daarom het die eerste breë kerkvergaderings in Nederland soos die Konvent van Wezel in 1568 en die Sinode van Emden in 1571 reeds aandag aan hierdie saak gegee. Voorsiening is gemaak vir proponente (wat as predikante beroepbaar is) en wat hulle studie voltooi het en 'een ander soort van proponenten'. Hierdie persone was mense wat hulle op grond van sekere gawes by die kerkraad aangemeld het om onder leiding van die predikant te oefen en te kwalifiseer om tot die amp toegelaat te word (De Gier 1989:58-59).

Saamgevat gaan dit hier om (teologies) onopgeleide persone met ' $n$ besondere, bruikbare kennis en behendigheid in die deurgee van die Woord aan 'n gemeente: tydens eredienste en in gevalle van geestelike nood. 'n Bekwaamheid wat meet- of toetsbaar is in die kerkverband en vergelykbaar is met soortgelyke, bestaande praktyke in gemeentes. Dit gaan ten slotte om besondere gawes vir die normale kerklike praktyk.

\section{Die DKO artikel 8: Die erkenning van besondere gawes}

Dit is een van die vrugte van ' $n$ kerkverband soos ' $n$ sinodale verband dat meer Christene in kerkregeervergaderings ${ }^{4}$ saam luister na God se Woord. 'n Saamluister wat tot beter besluite aanleiding kan/moet gee as besluite wat deur enkelinge of persone vanuit net een gemeente of kerklike omgewing geneem word. Daarom dat kosbare kerklike besittings soos belydenisskrifte en liturgiese formuliere wat aan die verband rigting moet gee, verkieslik die werk van die betrokke gemeentes gesamentlik moet wees (Strauss 2010:65). Van gelowiges as verteenwoordigers van gemeentes wat op 'n gelyke vlak sonder enige menslike (ook pouslike, biskoplike of moderatorse) hiërargie op mekaar kan inwerk om die Bybel reg te vertolk. 'n Situasie waarin almal se standpunte of insette met die deurpraat daarvan gehoor, aan die Woord gemeet en paslik hanteer word (Strauss 2010:41). 'n Omgewing waarin gelowiges mekaar inspireer om deur die Woord gelei en gekorrigeer te word. Paulus verwys na sy gebed vir die 'hele gemeenskap van gelowiges in die hemel en op die aarde' wat sy bestaan aan God te danke het en vervolg dan: 'Mag julle instaat wees om saam met al die gelowiges te begryp hoe wyd en ver en hoog en diep die liefde van Christus strek ...' (Ef 3:14, 18).

Hierdie 'saam met al die gelowiges' moet ook vanuit 'n gemeenskaplik-erkende standaard op die toelating van

4.NGKO 2013 artikel 18 praat byvoorbeeld van 'vier kerkvergaderinge' naamlik kerkraad, ring, sinode en algemene sinode. Dit beteken: hierdie vier vergaderinge regeer die kerkverband binne gemeente-, rings-, sinodale en algemene sinodale verband. Daarmee word die hele verband betrek (NGKO 2013:6). persone - opgeleid en onopgeleid - tot die amp van die bedienaar van die Woord toegepas word. Daarom is die toelating tot hierdie amp 'n saak van die breër kerk of kerkverband. Proponente en predikante wat deur hierdie proses gaan, is immers beroepbaar in die breë verband.

Ten opsigte van die weg tot toelating is die DKO eenvoudig. 'n Persoon wat as 'n artikel 8-predikant wil kwalifiseer, moet op aanbeveling van die provinsiale sinode waarbinne hy val, deur sy klassis geëksamineer word. Indien suksesvol, moet hy 'een tijdlang in het privé proponeren' waarop die klassis verder met hom 'stichtelijk' handel. Private proposisies beteken dat die kandidaat net voor predikante wat agterna kritiseer, preke opstel en voordra. Publieke proposisies geskied voor die hele gemeente en dien as ' $n$ aanvulling van universitêre opleiding. Teen die einde van die 17 de eeu raak DKO artikel 8-predikante egter in onbruik. Die gebruik vlam weer op met die kerklike afskeidings in die gereformeerde Nederland van 1834 (afskeiding), 1886 (doleansie) en 1907 (gereformeerde en oud-gereformeerde gemeente). Die kriterium wat op grond van artikel 8 toegepas word, bly ' $\mathrm{n}$ besondere, 'natuurlike' insig in die Woord en in die oordrag en toepassing daarvan (De Gier 1989:61-62; De Jong 1987:317-320,328-329): dus 'n eerbiediging van die konstante van die bediening van die Woord.

Kerke in die Dordtse kerkordelike tradisie hou hulle by predikante van singuliere gawes in hoofsaak by die wyse van toelating soos bepaal in DKO artikel 8 (vgl. Kruger et al. 1966:80). Hierdie toelating het die bekwaamheid om die Woord in die hele kerkverband te verkondig, in die oog.

Volgens Visser lyk toelating in die gereformeerde kerke in Suid-Afrika (GKSA) soos volg. 'n Kandidaat meld hom by sy kerkraad aan. Nadat die kerkraad hom vergewis het van die kandidaat se singuliere gawes, stuur hy die aansoek deur na die klassis. Dit gebeur egter eers nadat die kerkraad die aansoek na die teologiese skool gestuur het wat moet oordeel of die persoon aanvullende opleiding nodig het. By die voltooiing van hierdie opleiding verskaf die senaat van die teologiese skool 'n dokument wat die voltooiing van die studie staaf. Nou stuur die kerkraad 'n gemotiveerde aansoek na die klassis vergesél van die dokument van die senaat van die teologiese skool en 'n getuienis van die leer en lewenswandel van die aansoeker. Word die klassis oortuig van die singuliere gawes van die aansoeker, stuur hy die aansoek deur na die partikuliere of streeksinode vir goedkeuring. Nadat laasgenoemde die aansoek goedgekeur het, gaan die klassis oor tot die finale eksaminering met die oog op beroepbaarstelling. Die finale eksaminering volg egter op ' $n$ tyd waarin die kandidaat 'private preekproewe' lewer. Die preekproewe is nie amptelike Woordverkondiging nie, maar 'die spreek van 'n stigtelike woord'. Op die ontvangs van'n goedkeurende verslag hieroor, stel die klassis die kandidaat beroepbaar (Visser 1999:44).

Die Christian Reformed Church in North America (CRCN) volg deur die jare dieselfde lyn. 
Die kerkorde artikel 7 van die CRCN praat ook van uitsonderings vir mense wat 'singularly gifted' of toegerus is om die Woord te bedien. In die CRCN moet die klassis in die teenwoordigheid van sinodale afgevaardigdes sulke persone eksamineer om hulle buitengewone gawes te toets. Die klassis moet daarna die stappe vir beroepbaarstelling volg wat in sinodale besluite neergelê is (Engelhard \& Hofman 2001:63-70; Van Dellen \& Monsma 1967:45). Die metode dat so 'n persoon vanuit die eie omgewing aanbeveel word, maar dat die kerkverband ook ' $n$ rol speel by ' $n$ beoordeling van die singuliere gawes, bly dus gehandhaaf in die CRCN.

\section{Bouwman (1985) vat die saak soos volg saam:}

Zeker is echter, dat men door al te groote welwillendheid tegenover den candidaat de zaak des Heeren niet dient. Met personen, die nog al hoog van zich zelf denken, is de kerk des Heeren niet gebaat. Eerst dan wanneer anderen in iemand singuliere gaven ontdekken, en de kerk dezen persoon na ernstig onderzoek en voorbereiding in het ambt stelt, kan zulk een dienaar onder Gods zegen werkzaam zijn tot opbouw van het liggaam van Christus. (bl. 439)

Soos in die geval van opgeleide predikante, kom artikel 8-predikante uit die lidmate van die kerke of gemeentes, nie noodwendig uit huidige of oud-ouderlinge of diakens nie. Dit gaan dus om 'n roeping van die Here én gawes wat Hy vir die uitvoering van hierdie roeping skenk. Gawes om die Woord van Christus as die hoof van sy kerk gehoorsaam te bedien: om die volledige predikantwees van so ' $n$ persoon (Jonker 1965:8).

Die blywende behoefte wat geïdentifiseer is, is amptelike Woordbediening. ' $n$ Behoefte waarin die Here mense voorsien wat hierdie amp kan vervul. Waar die Woord heers, heers die Gees van die Woord en word die hoofskap van Christus erken.

\section{NGK: Oefenaars}

In hierdie artikel is daar verwys na die gebruik van DKO artikel 8 in die GKSA. Aangesien die DKO die geldende kerkorde in die NGK voor 1824 (vgl. Vorster 1960:12-18) was, was daar waarskynlik ook in die NGK vroeër sulke moontlikhede. Die ou voortrekker Sarel Cilliers wat die sogenaamde wenkommando na Bloedrivier vergesél het, het as ouderling ook in NGK-gemeentes gepreek. 'n Vergunning wat skynbaar - besonderhede ontbreek - deur die kanale van die NGK aan hom toegestaan is (Strauss 1995:10-11).

Veral in die eerste helfte van die 20ste eeu gebruik die NGK ook, soos dit populêr genoem is, die amp van 'Oefenaar en Catechiseermeester' (NGKSA KO 1936:19). In gereformeerde kerkregering funksioneer so 'n oefenaar nêrens as 'n erkende kerklike amp nie, maar toelating daartoe vertoon ooreenkomste met ' $n$ predikant met singuliere gawes in DKO artikel 8. Volgens die destydse wette en bepalinge van die Kaapse NGK kon iemand met die 'singuliere gaven' van godsaligheid, ootmoedigheid, sedigheid, 'n goeie verstand en diskresie, welsprekendheid en die begeerte om in die
'Wijngaard des Heeren' te werk (vgl. die ooreenkomste met DKO artikel 8), hom aanmeld vir die oefenaarskursus. Hierdie aanmelding geskied by die Kommissie vir die Eksamen van Sendelinge. Die kerkraad van 'n voornemende oefenaar moet van sy singuliere gawes getuig en die kommissie sal sy godsvrug en bekwaamheid ondersoek. Daarby moet hy ' $n$ algemene kennis van die Skrif, Bybelse aardrykskunde, die hooftrekke van die Kerkgeskiedenis, die gereformeerde belydenisse en die uitleg en toepassing van die Bybel besit. Nadat hy hieroor 'n eksamen geslaag het, sal hy toegelaat word as ' $n$ oefenaar en katkiseermeester (NGKZA KO 1909:96).

In sy gemeente sal die oefenaar op 'gezette en vooraf aangekondigde tijden' in byeenkomste 'over de Goddelijke waarheden handelen'. Hy mag nie in ' $\mathrm{n}$ ander gemeente sonder die toestemming van die predikant van daardie gemeente werk nie. Hy moet waak teen partyskappe in die gemeente en die kerkraad of predikant nie beoordeel nie. Verder moet hy hom aan die Woord en belydenisskifte van die NGK hou en die bywoning van die amptelike eredienste in sy gemeente bevorder (NGKZA KO 1909:96-97; NGKSA KO 1936:19-20).

In later jare, binne twee jaar nadat hy as oefenaar toegelaat is, moes die oefenaar by die kommissie wat hom toegelaat het, 'n verder eksamen' aflê in 'Pastoraal, Predikkunde, Kerkreg'. Die aflê van die eksamen moes vergesél wees van skriftelike 'bewyse' van goeie gedrag en getrouheid aan die wette en bepalinge van die NGK (NGKSA KO 1936:20). Oefenaars het hiermee meer gedetaillerde kerklike bindinge as die dominees gehad. Miskien was die verbod op partyskappe 'n maatreël gebore uit die praktyk, terwyl gehoorsaamheid aan die wette en bepalinge vir alle lidmate gegeld het. Wat die vakke waarin hy eksamen afgelê het, moontlik aandui, is dat hy moes help met preke, pastoraat en kerkregering. Hierdie take funksioneer egter nie in sy omskrewe werk nie.

Die oefenaar in die NGK was 'n buitengewone, eiesoortige kerklike figuur. Tog moes hy aan die Bybelse konstante van die sentrale posisie van die bediening van die Woord in die NGK gestalte gee. Hy was 'n buitengewone figuur, maar die prosedure by sy toelating was nie ' $n$ toepassing van DKO artikel 8 nie.

Skynbaar was die behoefte aan en funksionering van die oefenaar in die NGK nie groot nie. In 1936 word vier persone via die NGK se teologiese opleiding op Stellenbosch as oefenaars in die NGK toegelaat, in 1937 geen, in 1938 was daar twee, in 1939 geen en in 1940 een. In 1945 staak die Kaapse Sinode die 'amp van oefenaar' omdat dit nie meer in 'n 'wesenlike behoefte' voorsien nie (NGK in SA 1945:274). Die NGK sou na die vorming van sy algemene sinodale verband in 1962, ook nie die DKO artikel 8 handhaaf nie.

\section{NGK: Ouderlinge met preekvergunning}

Hoewel NGKO 2011 gemeet aan sy eerste weergawe in 1962, in sommige van sy bewoordings en in sy hoofstuk-indeling 
oriënteer op die $\mathrm{DKO},{ }^{5}$ het hy nie DKO artikel 8 oorgeneem nie. Daarmee het hy nie die idee van volledige predikantwees vanweë singuliere gawes sonder vooraf opleiding uit die 16de en 17de eeuse gereformeerde Nederland oorgeneem nie. Die grootste rede hiervoor is waarskynlik omdat die situasie van die NGK in 1962 skerp met die van die DKO in 1619 verskil. DKO artikel 8 het in die Nederlandse gereformeerde kerkgeskiedenis opgeleef as daar 'n afskeiding met 'n tekort aan predikante was. 'n Groter voorsiening van predikante het die fokus van singuliere gawes sonder opleiding verskuif na die 'normale' opleiding van predikante (Bouwman 1985:434).

Groot afstande en klein gemeentes ver van ander bring vir die huidige opnuut die behoefte aan nie-tradisioneel opgeleide, maar volledige predikers in die NGK as ' $n$ moderne gereformeerde kerk, na vore. Behalwe dat NGKO 2011 reeds ' $n$ reëling hiervoor getref het, het die saak waarskynlik die verste in die gebied van die Sinode van OosKaapland gevorder. Hier is die prosedure vir 'ouderlinge met preekvergunning' of die lei van eredienste deur ouderlinge reeds in die OKKO uitgewerk (OKKO 2014:I-16, I-17, I-18).

Op die klank af lei die benaming 'lidmate met preekvergunning' die aandag weg van DKO artikel 8 se predikante met singuliere gawes. Tog dui wesenlike elemente daarop dat dieselfde 'noodsituasie' in 'n gereformeerde kerk in beide gevalle hanteer word. Dit gaan in beide situasies om die volledige of outentieke bediening van die Woord deur 'n persoon wat nie iemand anders se preek voorlees of daarvan gebruik maak nie. Dit gaan om die bediening van die Woord soos deur iemand wat daarvoor opgelei, gelegitimeer en bevestig is (Kleynhans 1984:29-44).

OKKO praat van ongesensureerde belydende lidmate binne die konteks van NGKO 2011 'n vereiste vir enige kerklike amp en daarom nie ook nodig op hierdie punt nie (NGKO 2011:1-7) - wat oor die gawe en vermoë beskik om die Woord in 'n openbare erediens te bedien en die liturgie te lei. Iemand wat by die kerkraad aansoek doen om die Sinode van Oos-Kaapland se 'opleidingsprogram te deurloop'. Dit gaan hier dus ook om 'n gawe vir Woordbediening voordat daar enige opleiding plaasvind. ' $n$ Gawe wat moontlik - in die huidige situasie - soos in 1619 ook redelik uitsonderlik is. Die kerkraad moet hom van 'gawes en ander vermoëns' by die kandidaat vergewis naas sy of haar leer en lewe: van 'leersuiwerheid, lewenswandel ...'. 'n Persoon wat deur die kerkraad geskik geag word se naam word aan die ring/ ringskommissie gestuur. Die ring vergewis hom van die behoefte aan so ' $n$ bediening in die gemeentes binne sy gebied én die breër kerkverband. Die ring wend die persoon aan waar 'ringsleraars vanweë omstandighede nie op 'n gereelde grondslag beskikbaar is om eredienste te lei nie'. Anders as by die DKO, dra die mening van die kerkraad oor geskikheid hier skynbaar die swaarste gewig. Dit is egter

5.Vgl. J.D. Vorster se bekende benaming vir die NGKO 1962: Die "Dordtse Kerkorde aangepas by die eise van ons dag' (Vorster 1960:13) nie die kerkraad wat die persoon aanwend nie, maar die ring - waarskynlik in oorleg met die kerkraad van die betrokke gemeente en as ' $n$ instansie van oorleg tussen die ringsgemeentes waar die behoefte aan ' $n$ lidmaat met preekvergunning voorkom.

Na die goedkeuring deur die ring van die aansoek van die kandidaat - wat aanvanklike geskikheid of gawes insluit skryf die kerkraad die aansoeker vir opleiding in by die sinode. Na s yen/of haar suksesvolle opleiding word die lidmaat as 'n ouderling van die betrokke gemeente verkies met die opdrag 'Hulpbediening van die Woord'. Dit bly dus ' $n$ ouderling met preekvergunning. Daarom geld alle bepalinge vir kerkraadslede ook in sy/haar geval. Die ring of ringskommissie wys uit die ring 'n predikant aan wat hierdie ouderling 'deurlopend' begelei. Die begeleiding konsentreer op 'Woord- en leersuiwerheid' en die inkleding van die erediensliturgie. Dieselfde mentor of begeleier lewer jaarliks skriftelik verslag aan die ring oor die 'geskikheid' van die betrokke ouderling vir die bediening van die Woord. Die betrokke kerkraad onder wie se toesig hierdie ouderling preek, doen dieselfde. Hierdie verslag handel oor die geskikheid van die ouderling om die Woord te bedien én die voortgaande behoefte in die gemeente daaraan. Nadat die termyn van hierdie ouderling verstryk het, oorweeg die kerkraad 'andermaal' die toekoms van dieselfde twee sake. Opgeleide ouderlinge moet verdere toerusting deurloop en ouderlinge wat nie so opgelei is nie, kan slegs leesdienste waarneem (OKKO 2014:I-16, I-17, I-18).

Sy beleid vir die aanwending van opgeleide lidmate vir die 'Woordbediening en liturgiese leiding' dui aan dat die Sinode van Oos-Kaapland van 2007 van hierdie 'bedieningsnood' in kleiner gemeentes in die platteland kennis geneem het. Dit het eventueel gelei tot die opleiding van ouderlinge met preekvergunning. Die insiatief vir sulke lidmate lê by die kerkraad 'op aanbeveling van die ring' (Mouton 2010:1).

Wat gawes vir en die konsentrasie op die Woordbediening betref, verskil hierdie ouderling in essensie nie veel van 'n DKO artikel 8-predikant nie. Die funksie wat so 'n persoon vervul, stem ooreen met die van 'n DKO artikel 8-predikant. Ook in die opleiding en begeleiding is daar rakpunte. Die saak waarom dit in die 21ste eeu gaan, kom immers ooreen met die saak waarom dit in die 17 de eeu gegaan het: die bekwame bediening van die Woord. Tog verskil die ouderling met preekvergunning van die artikel 8-predikant daarin dat laasgenoemde ' $n$ amp met ' $n$ onbepaalde tyd beklee, terwyl eersgenoemde aan die ouderlingstermyn gekoppel bly. Boonop kry die ring se koördinering en vasstelling van so ' $n$ behoefte ' $n$ nie-gereformeerde ekstra by: die ring hou waarskynlik deurslaggewende - toesig oor hierdie ampswerk in die gemeente, hoewel saam of in oorleg met die kerkraad. Hierdie toesig lyk op die oog af breër, deegliker en meer intensief as die uitoefening van die eintlike taak van die ring: kerkvisitasie. So 'n reëling kan die kerkraad egter tot onmondigheid in die saak degradeer. As verteenwoordigers van die kerkverband kan die ring en die sinode ' $n$ rol speel in 
die beskikbaarstelling van iemand wat in meer as een gemeente bekwaam kan preek. Toesig oor ampsvervulling in die gemeente bly egter die verantwoordelikheid van die kerkraad. Immers, wat vir een ouderling geld, geld ook vir die ander. Hulle funksies mag verskil, maar hulle amp bly vergelykbaar of ewe waardig. ${ }^{6}$ Sy jaarlikse rapportering aan die ring kan die kerkraad stimuleer om die hele aangeleentheid met groeiende bekwaamheid te hanteer.

Intussen moet ' $n$ ander vraag gevra word: watter nut het die opleiding van ouderlinge om te preek as hierdie vergunning net vir 'n ouderlingstermyn geld? Sal 'n nuwe aanstelling na 'n tydperk van aflegging met hernude opleiding gepaard gaan? Wat meer is, gaan verdere opleiding - soos met voltydse dominees - verplig word? Is daar ook gedink oor 'amptelike' indiensopleiding naas die begeleiding deur predikante? Ek verwys nie na verdere toerusting nie, maar besinning en rigting in die proses van diens.

Dit bly ook 'n vraag watter rol die kerk se erkende teologiese opleiding in die saak speel? Sal die opleiding nie baat by insette van hierdie kant af nie? Kan die GKSA vir die NGK hierin as 'n voorbeeld (Visser 1999:44) dien?

\section{Slot}

'n Vergelyking tussen die DKO artikel 8-predikant in die Nederlandse Gereformeerde Kerk van 1619 en die ouderling met preekvergunning in die NGK van 2015 dui daarop dat die twee sake albei met konstantes vir die kerk werk; al dui DKO artikel 8 op die volledige predikantwees van die betrokkene en al werk die NGK met ouderlinge met preekvergunning. By beide gaan dit oor die amptelike bediening van die Woord deur persone wat deur instellings van die kerkverband as geskik beskou word. Die betrokkenheid van die kerkverband wil standaarde verseker én gemeentes help om bekwame, erkende bedienaars van die Woord te gebruik.

Hoewel die NGK, elke kerk, kan aanspraak maak op sy unieke situasie, kan gereformeerde kerke in die gees van die gereformeerdeekumeneby mekaar én uit hulle gereformeerde geskiedenis leer. Dit is opvallend hoeveel ooreenkomste - te midde van verskille - rondom 'spesiale' bedienaars van die Woord tussen die kerke hier genoem, voorkom. Die groot konstante saak wat beide in die kerklike praktyk wil dien, is

6.Vgl. Strauss, P.J., 2010:51 vir die anti-hierrargiese beginsel vir die kerklike ampte en -vergaderings. die poging om die lewe van die kerk vanuit en rondom die Woord van God te laat draai.

'n Opmerking van Koffeman (2009) is hier op sy plek:

Alleen al om de vrijheid van de verkondiging van het Woord zoveel mogelijk veilig te stellen, is een vorm van gestructureerd ambt vereist, ook al is ten aanzien van de vormgeving daarvan nog een grote variëteit denkbaar. (bl. 137)

\section{Literatuurverwysings}

Bos, F.L., 1950, De orde der kerk, Guido de Bres, Den Haag. Bouwman, H., 1985, Gereformeerd Kerkrecht I, De Groot Goudriaan, Kampen. De Gier, K., 1989, De Dordtse Kerkorde - een praktische verklaring, Den Hertog, Houten. De Jong, O., 1987, Geschiedenis der kerk, Callenbach, Nijkerk.

Du Toit, A.B., 1998, 'Ondersoek na 'n Nuwe Testamentiese basis vir die heraanpassing van die bedieningstruktuur in die Nederduitse Gereformeerde Kerk. Ned Geref Kerk.', Agenda van die Algemene Sinode. sn:sl, 217-221.

Engelhard, D.H. \& Hofman, L.J., 2001, Manual of Christian reformed church government, CRC, Grand Rapids, MI.

Jansen, J., 1952, Korte verklaring van de Kerkorde, Kok, Kampen.

Jonker, W.D., 1965, Om die regering van Christus in sy kerk, Unisa, Pretoria.

Kleynhans, E.P.J., 1984, Gereformeerde Kerkreg II, NG Kerkboekhandel Transvaal, Pretoria. Koffeman, L.J., 2009, Het goed recht van de kerk, Kok, Kampen.

Kruger, L.S., Du Plessis, H.L.M., Spoelstra, B. \& Spoelstra, T.T., 1966, Handleiding by die kerkorde, Pro Rege, Potchefstroom

Mouton, D., 2010, Beleid vir die aanwending van opgeleide lidmate vir die Woordbediening en liturgiese leiding, sn, sl.

Nauta, D., 1971, Verklaring van de kerkorde van de Gereformeerde Kerken in Nederland, Kok, Kampen.

Nederduitse Gereformeerde Kerk (NGKO) 2011, 2013, Die Kerkorde, sn, sl.

Nederduitse Gereformeerde Kerk in Suid-Afrika (NGKSA KO), 1936, Wette en aanvullende bepalinge, SA Bybelvereniging, Kaapstad.

Nederduitse Gereformeerde Kerk in Suid-Afrika (NGK in SA), 1945, Skema en werksaamhede van die Sinode, sn, sl.

Nederduitsch Gereformeerde Kerk in Zuid-Afrika (NGKZA KO), 1909, Wette en aanvullende bepalinge, Kerkkantoor, Kaapstad.

N.G. Kerk in Oos-Kaapland (OKKO), 2014, Die Kerkorde en aanvullende bepalinge en reglemente, sn, sl.

N.G. Kerk-Uitgewers 2004, Ons glo ..., NG Kerk-Uitgewers, Wellington (derde uitgawe, tweede druk).

Pont, A.D., 1981, Die historiese agtergronde van ons kerklike reg I, HAUM, Pretoria.

Rullman, J.C., 1933, Een man van singuliere gaven - Ds WH Gispen, Meinema, Delft.

Smit, C.J., 1984, God se orde vir sy kerk, NG Kerkboekhandel, Pretoria.

Spoelstra, B., 1989, Gereformeerde kerkreg en kerkregering, Teologiese Skool, Hammanskraal.

Strauss, P.J., 1995, Die Gees werk soos Hy wil, VCHO, Bloemfontein

Strauss, P.J., 2010, Kerk en orde vandag, Sunmedia, Bloemfontein.

Strauss, P.J., sa, Die bome roep, die klowe roep, NG Sendingpers, Bloemfontein.

Trimp, C., 1988, 'Ambt als dienst?', in P.J. Rossouw (ed.), Gereformeerde ampsbediening, pp 233-240, NG Kerkboekhandel, Pretoria.

Van Dellen, I en Monsma, M., 1967, The revised church order commentary, Zondervan, Grand Rapids, MI.

Visser, J., 1999, Die Kerkorde in praktyk, EFJS, Orkney.

Vorster, J.D., 1960, 'Die kerkorde vir die Ned Geref Kerke: Besware daarteen en betekenis daarvan', Ned Geref Teologiese Tydskrif (NGTT) 1(4), 12-18. 